\title{
Identified Motoneurons Involved in Sexual and Eliminative Functions in the Rat Are Powerfully Excited by Vasopressin and Tachykinins
}

\author{
Roch Ogier, Eliane Tribollet, Philippe Suarez, and Mario Raggenbass \\ Department of Basic Neurosciences, University Medical Center, CH-1211 Geneva 4, Switzerland
}

\begin{abstract}
The pudendal motor system is constituted by striated muscles of the pelvic floor and the spinal motoneurons that innervate them. It plays a role in eliminative functions of the bladder and intestine and in sexual function. Pudendal motoneurons are located in the ventral horn of the caudal lumbar spinal cord and send their axon into the pudendal nerve. In the rat, binding sites for vasopressin and tachykinin are present in the dorsomedial and dorsolateral pudendal nuclei, suggesting that these neuropeptides may affect pudendal motoneurons. The aim of the present study was to investigate possible effects of vasopressin and tachykinins on these motoneurons. Recordings were performed in spinal cord slices of young male rats using the whole-cell patch-clamp technique. Before recording, motoneurons were identified by $1,1^{\prime}$-dilinoleyl-3,3,3' $3^{\prime}$-tetramethylindocarbocyanine, 4-chlorobenzenesulfonate retrograde labeling. The identification was confirmed, a posteriori, by choline acetyltransferase immunocytochemistry. Vasopressin and tachykinins caused a powerful excitation of pudendal motoneurons. The peptide-evoked depolarization, or the peptide-evoked inward current, persisted in the presence of tetrodotoxin, indicating that these effects were mainly postsynaptic. By using selective receptor agonists and antagonist, we determined that vasopressin acted via vasopressin 1a (V1a), but not V1b, V2, or oxytocin receptors, whereas tachykinins acted via neurokinin 1 (NK1), but not NK2 or NK3, receptors. Vasopressin acted by enhancing a nonselective cationic conductance; in some motoneurons, it also probably suppressed a resting $\mathrm{K}^{+}$conductance. Our data show that vasopressin and tachykinins can excite pudendal motoneurons and thus influence the force of striated perineal muscles involved in eliminative and sexual functions.
\end{abstract}

Key words: cationic conductance; choline acetyltransferase; oxytocin; patch clamp; pudendal motoneurons; spinal cord

\section{Introduction}

Pudendal motoneurons are located in the ventral horn of the caudal lumbar spinal cord and project into the pudendal nerve. They innervate striated pelvic muscles involved in penile erection and ejaculation as well as the external urethral and anal sphincters. In most mammals, pudendal motoneurons are found within a single cell group, the Onuf's nucleus (Ueyama et al., 1984; Roppolo et al., 1985; Pullen et al., 1997). In the rat, they are distributed in two separate nuclei: the dorsomedial nucleus (DM) and the dorsolateral nucleus (DL), located in spinal segments L5 and L6 (Schroder, 1980; Sachs, 1982; McKenna and Nadelhaft, 1986). In the male, the DM innervates the bulbocavernosus and the levator ani and the external anal sphincter. In the female, the DM is much smaller and contains only motoneurons innervating the external anal sphincter. The DL innervates the ischiocavernosus

Received April 3, 2006; accepted Aug. 31, 2006.

This work was supported in part by the Swiss National Science Foundation and the Fondation Carlos et Elsie de Reuter, Geneva, Switzerland (E.T., M.R.). R.O. was supported by the Swiss National Science Foundation MD-PhD program (Foundation Professor Max Cloëtta, Zurich, Switzerland). We thank Dr. M. Manning (Department of Biochemistry, Medical College of Ohio, Toledo, $\mathrm{OH}$ ) for the supply of the V1b receptor agonist and the V1a receptor antagonist. We also thank D. Machard and A. Dupré for excellent technical assistance.

Correspondence should be addressed to Dr. Mario Raggenbass, Department of Basic Neurosciences, University Medical Center, 1 rue Michel-Servet, CH-1211 Geneva 4, Switzerland. E-mail: mario.raggenbass@medecine.unige.ch.

D01:10.1523/JNEUROSCI.3364-06.2006

Copyright $\odot 2006$ Society for Neuroscience $\quad 0270-6474 / 06 / 2610717-10 \$ 15.00 / 0$ muscle and the external urethral sphincter in the male but only the latter muscle in the female.

The properties of pudendal motoneurons suggest that they constitute a neuronal population distinct from other motoneurons. (1) They are sexually dimorphic, a property shared by their target muscles (Breedlove and Arnold, 1980; Jordan et al., 1982). (2) Their postnatal survival is dependent on androgens (Breedlove and Arnold, 1983; Nordeen et al., 1985). (3) They retain developmental characteristics in adulthood (Jordan et al., 1989; Nacimiento et al., 1993; Koliatsos et al., 1994; Tribollet et al., 1997). (4) They display unusual survival capacity or vulnerability in neurodegenerative diseases (Kihira et al., 1997; Mannen, 2000).

Pudendal motoneurons play a critical role in sexual and eliminative functions, and lesions in pathways controlling their activity can be devastating. Knowledge of their sensitivity to neurotransmitters/neuromodulators may be important for rescuing at least part of these functions in case of spinal cord injury or disease. Although some information on the basic electrophysiological properties of cat and rat pudendal motoneurons is available (Manabe et al., 1991; Sasaki, 1991; Fedirchuk and Shefchyk, 1993; Fedirchuk et al., 1994), virtually nothing is known about their sensitivity to neurotransmitters/neuromodulators. In male rats, pudendal nuclei express a high amount of vasopressin binding sites (Tribollet et al., 1997; Liu et al., 2003) and substance P bind- 
ing sites (Charlton and Helke, 1985). In addition, substance $\mathrm{P}$-immunoreactive axons converge on single, identified pudendal motoneurons of the cat (Tashiro et al., 1989a,b). The main objective of the present work was to investigate whether vasopressin and tachykinins can affect pudendal motoneurons and, if it is the case, to determine the pharmacological profile of the receptors involved. Whole-cell recordings were performed in spinal cord slices of young male rats. Motoneurons were identified by $1,1^{\prime}$ dilinoleyl-3,3,3', 3' -tetramethylindocarbocyanine,

4-chlorobenzenesulfonate (Fast DiI) retrograde labeling. The identification was confirmed, a posteriori, by choline acetyltransferase (ChAT) immunocytochemistry. The sensitivity of pudendal motoneurons to neuropeptides was investigated by using selective vasopressin and tachykinin receptor agonists and antagonist. We show that pudendal motoneurons are powerfully excited by vasopressin and tachykinins, a property shared by motoneurons innervating the hindleg, and that these effects are mediated by vasopressin 1a (V1a) and neurokinin 1 (NK1) receptors, respectively.

\section{Materials and Methods}

Spinal cord slices. Rats used were of the Sprague Dawley strain (Charles River Laboratories, Iffa Credo, L'Arbresle, France). Neonate male animals, $6-10 \mathrm{~d}$ old, were anesthetized (pentobarbital, $50 \mathrm{mg} / \mathrm{kg}$, i.p.) and killed by decapitation in accordance with the rules of the Swiss Federal Veterinary Office. The spinal cord was rapidly removed, and the lumbosacral region was isolated, embedded in 5\% agar, and submerged in ice-cold perfusion solution (see below), saturated with $95 \% \mathrm{O}_{2} / 5 \% \mathrm{CO}_{2}$ and from which $\mathrm{Ca}^{2+}$ was omitted. Transverse slices, $300 \mu \mathrm{m}$ thick, were cut using a vibrating microtome (Campden Instruments, Loughborough, UK). A slice containing pudendal motor nuclei was transferred to a recording chamber mounted on a Nikon (Tokyo, Japan) Eclipse E600FN, equipped with $40 \times, 0.8$ numerical aperture water-immersion objective, differential interference contrast optics, and an infraredsensitive video camera (C 25400-07; Hamamatsu, Schüpfen, Switzerland). Slices were continuously perfused with a solution containing the following (in $\mathrm{mm}$ ): $135 \mathrm{NaCl}, 15 \mathrm{NaHCO}_{3}, 5 \mathrm{KCl}, 1 \mathrm{MgCl}_{2}, 2 \mathrm{CaCl}_{2}$, and 10 glucose (saturated with $95 \% \mathrm{O}_{2} / 5 \% \mathrm{CO}_{2}, \mathrm{pH} 7.3-7.4$, and thermoregulated at $\left.32-33^{\circ} \mathrm{C}\right)$. Before whole-cell recordings, pudendal motoneurons labeled retrogradely with Fast DiI were visualized under fluorescence with the help of appropriate filters. All of the compounds tested were added to the perfusion solution at the concentration indicated.

Whole-cell recordings. Whole-cell current-clamp and voltage-clamp recordings were performed using patch pipettes pulled from borosilicate glass capillaries ( $1.5 \mathrm{~mm}$ outer diameter and $0.86 \mathrm{~mm}$ internal diameter; Harvard Apparatus, Les Ulis, France). In most recordings, pipettes were filled with the following solution (in $\mathrm{mm}$ ): $140 \mathrm{~K}$-gluconate, $10 \mathrm{KCl}, 10$ HEPES, $4 \mathrm{MgCl}_{2}, 0.1$ BAPTA, $2 \mathrm{Na}_{2}$-ATP, $0.4 \mathrm{Na}_{2}$-GTP, pH 7.2-7.3 adjusted with $\mathrm{NaOH}$. Some recordings were done with a pipette solution in which $\mathrm{K}$-gluconate and $\mathrm{KCl}$ were replaced by an equimolar amount of $\mathrm{CsCl}$. For these pipette solutions, the calculated liquid junction potentials were 14.9 and $7.3 \mathrm{mV}$, respectively (Clampex Junction Potential Calculator; pClamp software). In view of histological identification of the recorded motoneuron, the pipette solution was sometimes supplemented with $5 \mathrm{~mm}$ biocytin. Current and voltage signals were recorded, amplified, and digitized using an Axopatch 200A amplifier, a Digidata 1320A interface, and pClamp software (Molecular Devices, Sunnyvale, CA). Current signals were low-pass filtered at $2 \mathrm{kHz}$ and digitized at 5-10 $\mathrm{kHz}$. Series resistance was compensated by $60-80 \%$. Uncompensated series resistance $>30 \mathrm{M} \Omega$ resulted in rejection of the recording. Average data are expressed as mean \pm SEM.

Labeling of motoneurons. Intraperitoneal injection of fluorescent dyes, such as fast blue, true blue, or fluorogold, labels efficiently spinal cord motoneurons and autonomic neurons (Leong and Ling, 1990). We obtained similar results by using the lipophilic neuronal tracer Fast DiI. In particular, pudendal motoneurons were intensely labeled (see Fig. $1 B$ ). Fast DiI was dissolved at a final concentration of $2 \%(\mathrm{w} / \mathrm{v})$ in DMSO.
Rats at postnatal day 2-8 were anesthetized as described above and injected with Fast DiI $(20 \mu \mathrm{l})$ into the peritoneal space. Animals were killed 1-5 d after Fast DiI injection, and spinal cord slices were prepared (see above). Labeled pudendal motoneurons were visualized with the help of appropriate filters.

Immunocytochemistry. To assess the anatomical organization of pudendal motor nuclei in neonate rats, male animals aged of $10-13 \mathrm{~d}$ were anesthetized as described above and perfused through the left ventricle by gravity feed with physiological saline for $2 \mathrm{~min}$, followed by $50 \mathrm{ml}$ of fixative solution, i.e., $4 \%$ paraformaldehyde in $0.1 \mathrm{~m}$ PBS, pH 7.4. The lumbosacral portion of the spinal cord was dissected out, postfixed overnight in the same fixative solution, immersed for $2 \mathrm{~d}$ in a $30 \%$ sucrose solution in PBS, and cut in $40-\mu \mathrm{m}$-thick coronal sections in a cryostat. Sections were collected in PBS and bathed $30 \mathrm{~min}$ in PBS containing $0.3 \%$ hydrogen peroxide, to suppress endogenous peroxidase activity, 30 $\mathrm{min}$ in PBS containing $0.5 \%$ caseine, and $30 \mathrm{~min}$ (three times for $10 \mathrm{~min}$ ) in PBS containing 0.3\% Triton X-100, 0.1 M L-lysine, and $0.1 \%$ sodium azide. Sections were then incubated overnight at room temperature under constant agitation with a goat polyclonal antibody to ChAT at 1:250 (AB144P; Chemicon, Temecula, CA). Immunostaining was performed using a biotinylated horse anti-goat antibody at 1:200 (BA-9500; Vector Laboratories, Burlingame, CA) and an avidin-biotin detection system (Vectastain Elite, ABC kit; Vector Laboratories) according to the protocol of the manufacturer. Both the primary and the secondary antibodies were diluted in PBS containing 0.3\% Triton X-100, 0.1 M L-lysine, and $0.1 \%$ sodium azide. The sections were then rinsed twice (two times for 10 $\mathrm{min}$ ) in PBS, rinsed once in distilled water, mounted onto gelatinchrome alum-coated slides, dried, dehydrated with ethanol, and embedded in Eukitt. Sections were examined with bright-field illumination.

To confirm that the recorded neurons were motoneurons, spinal cord slices containing biocytin-filled cells were processed for ChAT immunocytochemistry. Slices were first immersed for $2 \mathrm{~h}$ in $4 \%$ paraformaldehyde dissolved in $0.1 \mathrm{~m} \mathrm{PBS}, \mathrm{pH} 7.4$, and then overnight in $30 \%$ sucrose dissolved in the same buffer. They were frozen flat between two glass coverslips and cut into $40-\mu \mathrm{m}$-thick sections in a cryostat. Sections were mounted onto gelatin-chrome alum-coated slides, washed with Trissaline buffer $(0.5 \mathrm{~m}$ Tris and $0.25 \mathrm{M} \mathrm{NaCl}, \mathrm{pH} 7.4)$ for $20 \mathrm{~min}$, and incubated for $4 \mathrm{~h}$ at room temperature in the presence of fluorescein isothiocyanate (FITC)-conjugated streptavidin (016-090-084; Jackson ImmunoResearch, West Grove, PA) at 1:150. The sections containing biocytin-labeled cells were then incubated overnight in the presence of the goat polyclonal antibody to ChAT (AB144P; Chemicon) at 1:100. Sections were further incubated for $4 \mathrm{~h}$ in the cyanine 3 (Сy3)conjugated donkey anti-goat antibody (705-165-147; Jackson ImmunoResearch) at 1:50. All antibodies were diluted in Tris-saline buffer, with two washes for $10 \mathrm{~min}$ in Tris-saline buffer being performed between two successive steps. Labeled neurons were visualized with appropriate filters. Sections were photographed with the Olympus Optical (Tokyo, Japan) DP10 digital camera. Images were slightly adjusted for brightness and contrast using Adobe Photoshop software and were assembled using Adobe Illustrator software (Adobe Systems, San Jose, CA).

Chemical compounds. $\left[\mathrm{Arg}^{8}\right]$-vasopressin, $\left[\mathrm{Thr}^{4}, \mathrm{Gly}^{7}\right]$-oxytocin (TGOT), a selective oxytocin receptor agonist (Lowbridge et al., 1977; Grzonka et al., 1983), and [deamino-Cys ${ }^{1}, \mathrm{Val}^{4}, \mathrm{D}-\mathrm{Arg}^{8}$ ]-vasopressin (dVDAVP), a selective V2 receptor agonist (Sawyer et al., 1981), were purchased from Bachem (Bubendorf, Switzerland). [1-Deamino-4cyclohexylalanine] arginine vasopressin (d[Cha $\left.\left.{ }^{4}\right] \mathrm{AVP}\right)$ (Derick et al., 2002 ) is a recently synthesized selective $\mathrm{Vlb}$ receptor agonist and $\mathrm{HO}-$ Phaa-D-Tyr(Me)-Phe-Gln-Asn-Arg-Pro-Arg- $\mathrm{NH}_{2}$ (VPA) is a selective V1a receptor antagonist (Manning et al., 1992). Both were kindly donated by Dr. M. Manning (Department of Biochemistry and Molecular Biology, Medical College of Ohio, Toledo, OH). Substance $\mathrm{P}$, $\left(\operatorname{sar}^{9}{ }^{9}\right.$,met $\left.\left(\mathrm{O}_{2}\right)^{11}\right)$-substance $\mathrm{P}\left(\operatorname{sar}^{9}\right.$-SP), an NK1-selective agonist, $(\beta$ $\mathrm{ala}^{8}$ )-neurokinin $\mathrm{A}(4-10)$ ( $\beta$-ala-NKA), an NK2-selective agonist, and succinyl-( $\operatorname{asp}^{6}, N$-me-phe $\left.{ }^{8}\right)$-substance $\mathrm{P}(6-11)$ (senktide), an NK3selective agonist, were purchased from Bachem. For reviews on agonists of tachykinin receptors, see Regoli et al. $(1988,1994)$. 

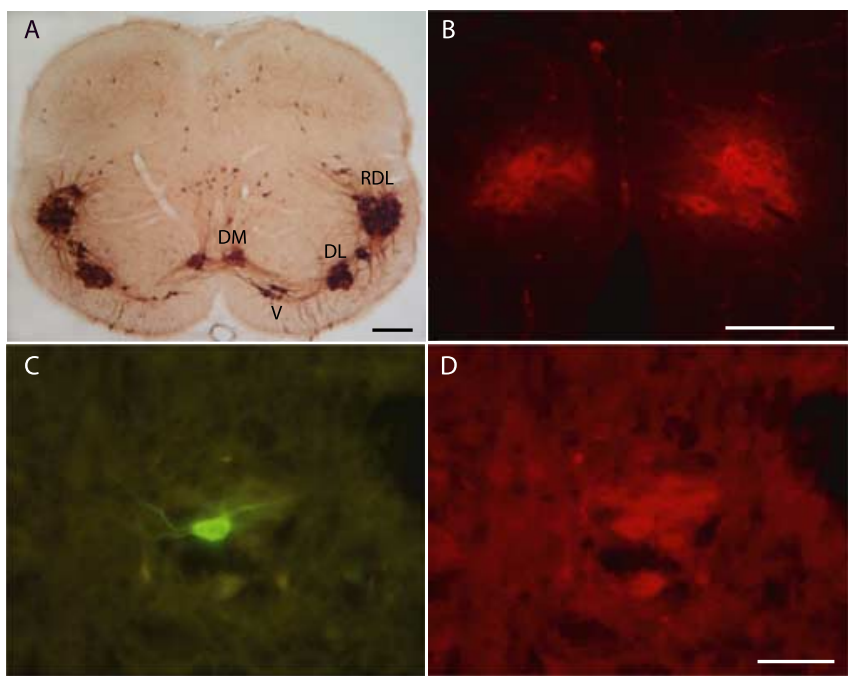

D

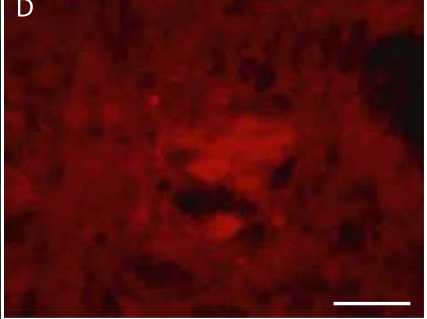

Figure 1. Identification of pudendal motoneurons in neonate rats. $A$, Coronal section of the spinal cord from a 10-d-old rat showing the immunostaining of ChAT at segmental level L6. Pudendal motoneurons are grouped in DM and DL nuclei. The RDL, which projects to the hindleg, and the ventral nucleus (V), which projects to the pelvic diaphragm, are also detectable, as are isolated immunoreactive cells scattered in the medial and dorsal central gray. $\boldsymbol{B}$, Photomicrograph illustrating the Fast Dil retrograde labeling of DM motoneurons. The spinal cord section is from a $10-\mathrm{d}$-old rat that had received an intraperitoneal injection of Fast Dil $24 \mathrm{~h}$ before. The animal was fixed by intracardiac perfusion of a solution containing $4 \%$ paraformaldehyde in $0.1 \mathrm{M}$ PBS. Note, by comparing $A$ and $\boldsymbol{B}$, that Fast Dil-labeled DM nuclei are easily recognizable by their shape and position along the midline. $\boldsymbol{C}, \boldsymbol{D}$, Identification of a recorded biocytin-loaded DM motoneuron. $\boldsymbol{C}$, Biocytin was visualized by treatment of the section with FITC-conjugated streptavidin. $\boldsymbol{D}$, The biocytin-labeled motoneuron was immunoreactive for $\mathrm{ChAT}$, detected with a Cy3-conjugated secondary antibody. Scale bars: $\boldsymbol{A}, 200 \mu \mathrm{m} ; \boldsymbol{B}, \boldsymbol{D}$ (for $\boldsymbol{B}-\boldsymbol{D}$ ), $100 \mu \mathrm{m}$.

\section{Results}

\section{Identification of motoneurons}

The distribution of ChAT immunoreactivity in spinal segment L6 of a 10-d-old male rat is illustrated in Figure $1 \mathrm{~A}$. Motoneurons are strongly immunoreactive, and their location is similar to that described at the same segmental level in the adult male rat (McKenna and Nadelhaft, 1986). The pudendal motor nuclei DM and DL are clearly recognizable, as are the retrodorsolateral nucleus (RDL), which projects to hindleg muscles (Schroder, 1980), and ventral nucleus, which innervates the pelvic diaphragm (Schroder, 1980). Interestingly, dense bundles of immunoreactive processes are also evidenced between all motor nuclei, possibly representing the anatomical substrate of functional connections, as previously suggested for the adult rat (McKenna and Nadelhaft, 1986; Peshori et al., 1995). Figure $1 A$ also highlights the small size of pudendal motor nuclei. As a consequence, these nuclei cannot be easily localized in acute spinal cord slices under infrared video microscopy. To identify motoneurons with certainty before recording, they were retrogradely labeled with a fluorescent dye, Fast DiI, injected into the peritoneal space $1-5 \mathrm{~d}$ before the experiment. This procedure resulted in a strong and selective labeling of spinal motoneurons and preganglionic sympathetic and parasympathetic neurons. Figure $1 B$ shows that the labeled DM nucleus can be easily identified, with Fast DiI concentrated in the cytoplasm of motoneuron cell bodies.

In total, recordings were obtained from $43 \mathrm{DM}$ and $21 \mathrm{DL}$ motoneurons identified by Fast DiI labeling. To further confirm that they were motoneurons, 12 DM motoneurons were injected with biocytin during the recording session and processed for ChAT immunoreactivity (Fig. 1C,D). All twelve were positive for ChAT and located within a medial ChAT-positive cell pool, iden- tified as the DM nucleus. For comparison, recordings were also obtained from 21 identified nonpudendal motoneurons located in either the RDL nucleus or lumbar motor nuclei positioned rostrally to pudendal motor nuclei.

\section{Effect of vasopressin on identified DM and DL pudendal motoneurons}

When recorded with K-gluconate-containing patch pipettes, DM pudendal motoneurons had an average cell input resistance of $91 \pm 19 \mathrm{M} \Omega$ (range, 33-482 M $; ; n=23$ ). In current clamp, they had resting membrane potentials ranging from -70 to $-50 \mathrm{mV}$ and were usually silent. Their minimal frequency of discharge, tested by injecting depolarizing current pulses of appropriate amplitude (Pierson et al., 2001), ranged from 7 to $12 \mathrm{~Hz}$.

The effect of vasopressin on DM motoneurons was tested on a sample of 19 cells. In current clamp, the neuropeptide $(0.1-0.5$ $\mu \mathrm{M})$ caused a reversible excitation in all motoneurons tested. In some motoneurons, which were silent in control conditions, the depolarization generated by vasopressin was sufficient to elicit action potential firing, the peak firing frequency being $8 \pm 1 \mathrm{~Hz}$ (range, 5-12 Hz; $n=7$ ) (Figs. 2, 3). The vasopressin-evoked depolarization ranged from 7 to $15 \mathrm{mV}$ and was on average $11 \pm$ $1 \mathrm{mV}(n=5)$. The peptide-induced depolarization persisted in the presence of tetrodotoxin (TTX) $(0.5 \mu \mathrm{M})$ and was, on average, $11 \pm 3 \mathrm{mV}$ (range, $4-17 \mathrm{mV} ; n=5$ ) (Fig. 3). This suggests that the vasopressin effect was mainly, if not completely, postsynaptic. In motoneurons recorded in the voltage-clamp mode (holding potential, -55 to $-75 \mathrm{mV}$ ), vasopressin evoked a sustained inward current that ranged from 45 to $200 \mathrm{pA}$ and had an average value of $124 \pm 22 \mathrm{pA}(n=7)$ (Fig. 3$)$.

The pharmacological profile of the receptors mediating the direct effect of vasopressin on pudendal motoneurons was determined by making use of selective agonists of vasopressin and oxytocin receptors. In DM pudendal motoneurons, the selective $\mathrm{V} 2$ receptor agonist $\operatorname{dVDAVP}(1 \mu \mathrm{M} ; n=4)$ and the selective V1b receptor agonist $\mathrm{d}\left[\mathrm{Cha}^{4}\right] \operatorname{AVP}(1 \mu \mathrm{M} ; n=4)$ were without effect (Fig. 2). The oxytocin receptor agonist TGOT $(0.1-0.5 \mu \mathrm{M})$ was tested on five motoneurons (three recorded in the normal perfusion solution, the remaining two in the presence of TTX at 0.5 $\mu \mathrm{M})$. TGOT did not induce any depolarization in any of these motoneurons but slightly increased the membrane noise in some of them (Fig. 3, second trace). In contrast, in all of these cells, vasopressin $(0.1-0.5 \mu \mathrm{M})$ evoked a depolarization or action potential firing.

DL pudendal motoneurons had a cell input resistance of $76 \pm$ $20 \mathrm{M} \Omega$ (range, $14-364 \mathrm{M} \Omega ; n=18$ ). The effect of vasopressin on DL motoneurons was tested on a sample of nine cells. The neuropeptide $(0.2-0.5 \mu \mathrm{M})$ caused excitation in all of them. In current clamp, the vasopressin-induced depolarization in two motoneurons was 7 and $8 \mathrm{mV}$, and the induced peak firing frequency in three motoneurons was $8 \pm 2 \mathrm{~Hz}$ (range, $6-11 \mathrm{~Hz}$ ). In voltage clamp, the vasopressin-evoked inward current was $74 \pm 13 \mathrm{pA}$ (range, $40-120 \mathrm{pA} ; n=5$ ). The selective $\mathrm{V} 2$ receptor agonist dVDAVP $(0.5-1 \mu \mathrm{M} ; n=3)$ and the selective V1b receptor agonist $\mathrm{d}\left[\mathrm{Cha}^{4}\right] \mathrm{AVP}(0.5-1 \mu \mathrm{M} ; n=3)$ were without effect. In addition, the selective V1a antagonist VPA (50-100 nM) suppressed the vasopressin response in three of three motoneurons (Fig. $4 A, B)$.

Together, our data show that pudendal motoneurons, located in either the DM or the DL nucleus, are directly excited by vasopressin acting on $\mathrm{V} 1$ a receptors. 


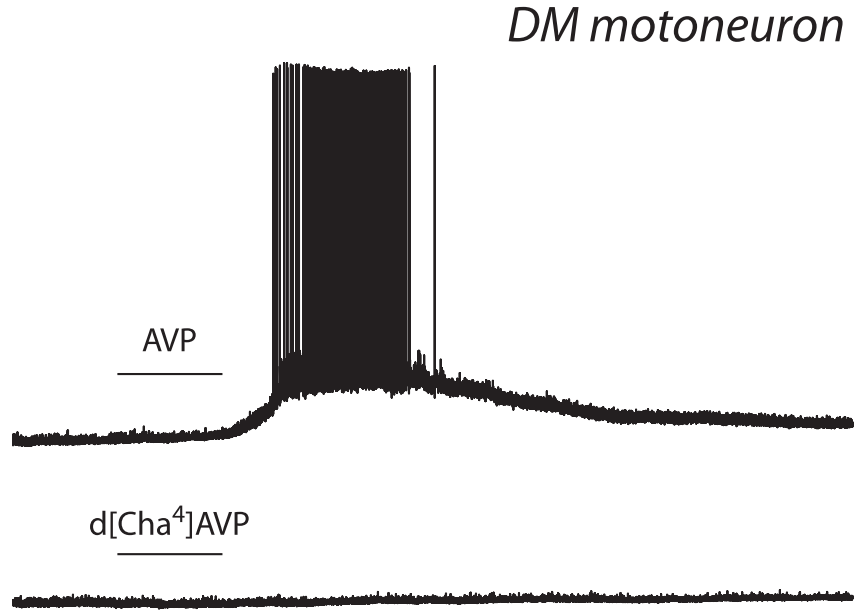

dVDAVP

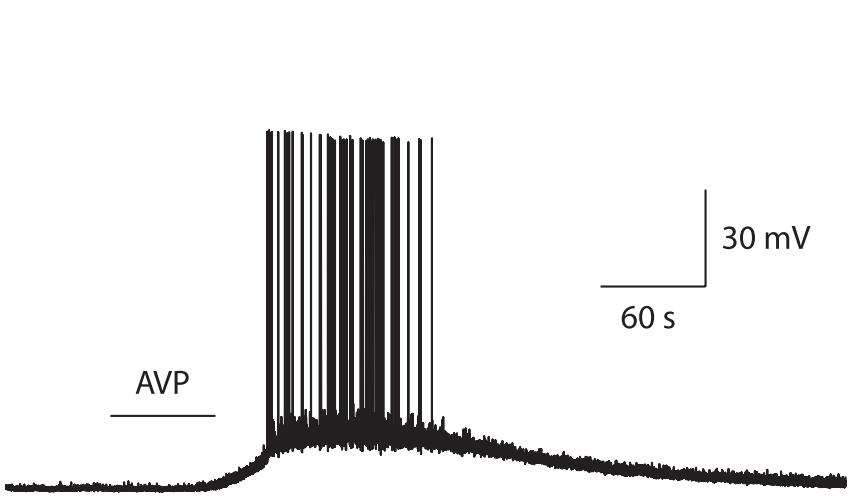

Figure 2. Effect of vasopressin and of selective agonists of V1b and V2 receptors on an identified DM pudendal motoneuron. Current-clamp records obtained in the presence of 0.1 $\mu \mathrm{m}$ vasopressin (AVP; top and bottom traces), $\left.1 \mu \mathrm{m} \mathrm{d[Cha}{ }^{4}\right]$ AVP (second trace), and $1 \mu \mathrm{m}$ dVDAVP (third trace). In this figure and in Figures 3,4 , and $6-8$, the horizontal bar above a voltage or current trace indicates the time during which an agonist was present in the perfusion solution. Note that vasopressin depolarized the motoneuron and induced action potential firing, whereas neither $\mathrm{d}\left[\mathrm{Cha}{ }^{4}\right] \mathrm{AVP}$, a V1b receptor agonist, nor dVDAVP, a V2 receptor agonist, had any effect.

\section{Mechanism of action of vasopressin}

To gain some information on the membrane mechanism responsible for the excitatory effect of vasopressin in pudendal motoneurons, we tested the effect of $\mathrm{Cs}^{+}$, a broad-spectrum blocker of $\mathrm{K}^{+}$channels. Seven DM pudendal motoneurons were recorded using patch pipettes filled with a Cs-methanesulfonatecontaining solution. In these motoneurons, vasopressin either elicited a depolarization of $7 \pm 2 \mathrm{mV}$ (range, $6-10 \mathrm{mV} ; n=3$ ) or generated an inward current of $98 \pm 32$ pA (range, 50-190 pA; $n=4$ ). These results indicate that Cs-sensitive $\mathrm{K}^{+}$channels probably do not play an exclusive role in the mechanism of action of vasopressin.

In a second set of experiments, we tested the effect of vasopressin on the motoneuron current-voltage $(I-V)$ relationship. $I-V$ relationships were established in the absence (control $I-V$ ) and in the presence (test $I-V$ ) of vasopressin, added to the perfusion solution at $0.2-1 \mu \mathrm{M}$. The following protocol was used: the
DM motoneuron
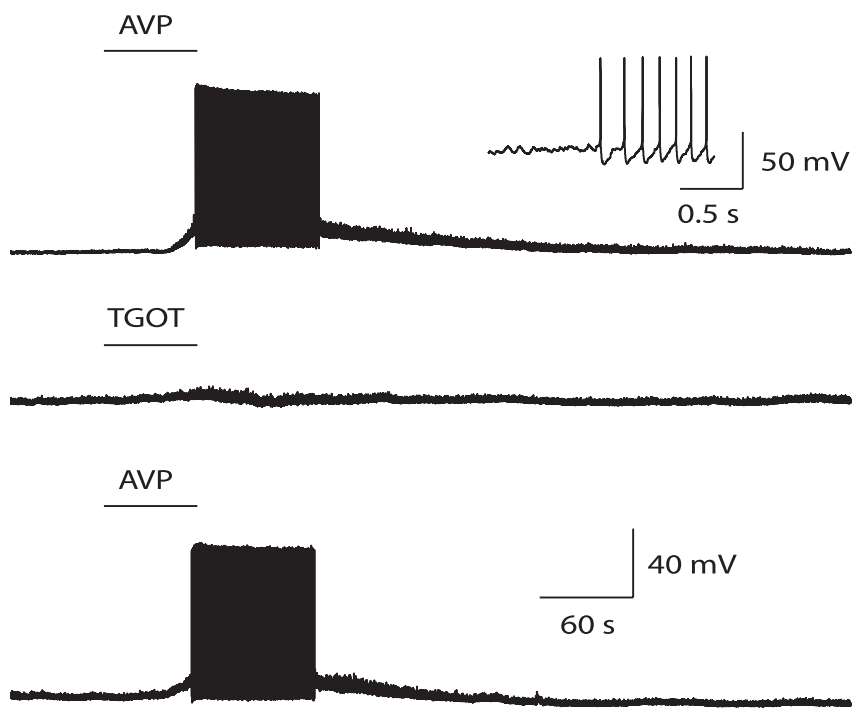

\section{AVP}
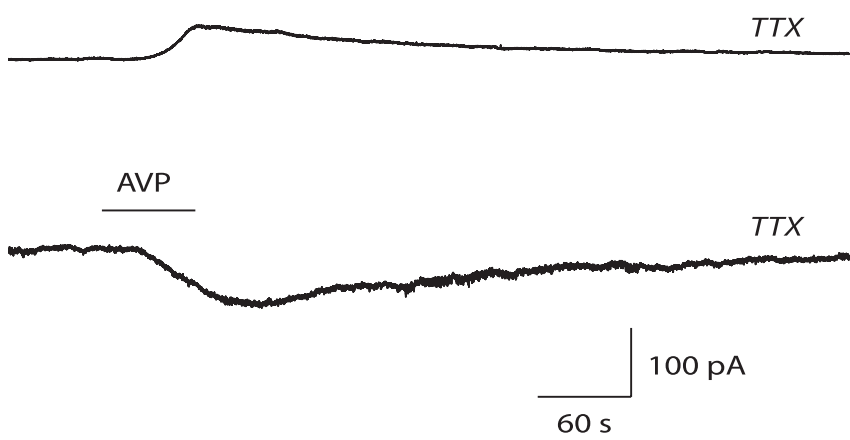

Figure 3. Effect of vasopressin and of a selective oxytocin receptor agonist on an identified DM pudendal motoneuron. Current-clamp records obtained in the presence of 0.5 and $0.1 \mu \mathrm{M}$ vasopressin (AVP; top and third traces, respectively), in the presence of $0.5 \mu \mathrm{m}$ vasopressin and $0.5 \mu \mathrm{M}$ TTX (fourth trace), and in the presence of $0.5 \mu \mathrm{M}$ TGOT (second trace). The inset in the top trace shows a detail of the membrane potential at the beginning of the vasopressin-evoked firing. Bottom trace, Voltage-clamp recording showing the inward current elicited by vasopressin at $0.5 \mu \mathrm{M}$, in the presence of TTX, in this same motoneuron. Note that, contrary to vasopressin, TGOT, an oxytocin receptor agonist, did not induce any depolarization, although in this motoneuron it caused a slight increase in membrane noise. Note also that the vasopressininduced depolarization and inward current persisted in the presence of TTX, i.e., in conditions of synaptic uncoupling.

motoneuron was held at a depolarized potential for $0.75 \mathrm{~s}$, a hyperpolarizing voltage ramp command was then delivered (rate $230 \mathrm{mV} / \mathrm{s}$ ), and the current response was recorded. The net vasopressin-induced current was computed by subtracting the control $I-V$ relationship from the test $I-V$ relationship. In two motoneurons, recorded with K-gluconate-containing patch pipettes, the net vasopressin-evoked current showed slight outward rectification and reversed in polarity at -49 and $-26 \mathrm{mV}$ (Fig. $5 A$ ). In two other motoneurons, the vasopressin current was also slightly outward rectifying but failed to reverse at any potential. In three additional motoneurons, the vasopressin current varied linearly with the membrane potential and approached zero at hyperpolarized potentials, i.e., at $-134,-120$, and -114 $\mathrm{mV}$ (Fig. 5B). In one motoneuron, recorded with Csmethanesulfonate-containing patch pipettes, the net vasopressin 
A

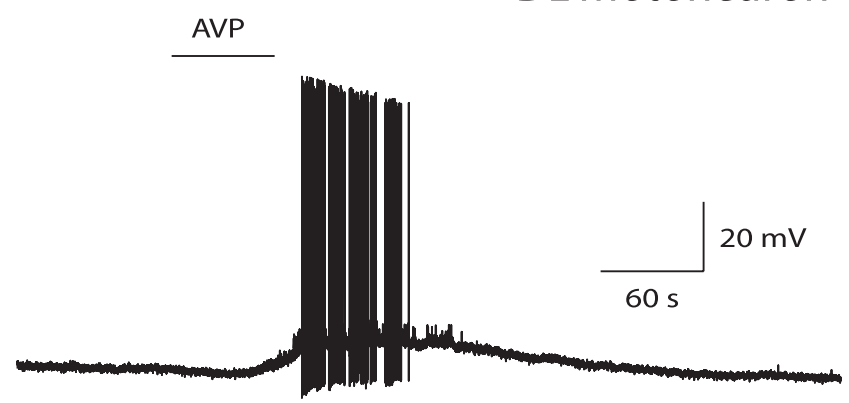

AVP

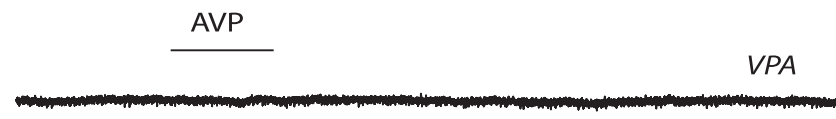

B

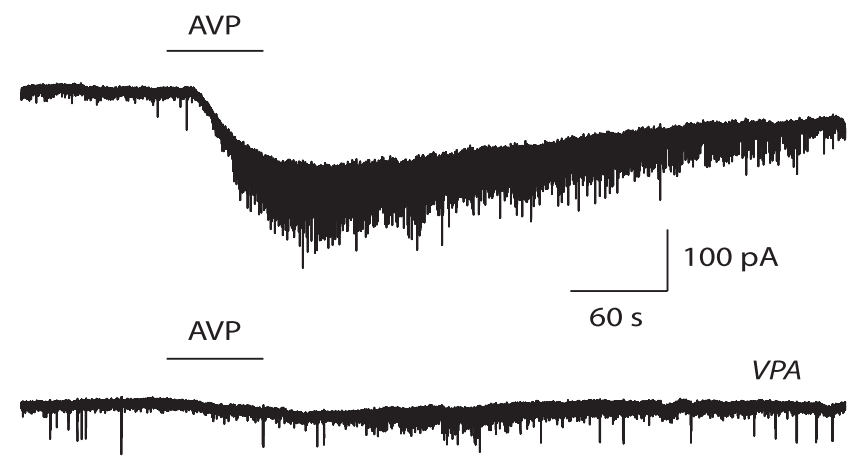

Figure 4. Effect of vasopressin and of a V1a receptor antagonist on identified DL pudendal motoneurons. $A$, Current-clamp records obtained in the presence of $0.5 \mu \mathrm{m}$ vasopressin (AVP; top trace) and in the presence of both vasopressin and $0.1 \mu \mathrm{m}$ of the V1a selective antagonist VPA (bottom trace). $\boldsymbol{B}$, Voltage-clamp records obtained in a second DL pudendal motoneuron. They show the inward current evoked by vasopressin at $0.5 \mu \mathrm{m}$ (AVP; top trace) and by vasopressin coapplied with $50 \mathrm{~nm}$ of the V1a receptor antagonist VPA (bottom trace). Note that the V1a receptor antagonist suppressed the vasopressin response.

current reversed in polarity at $-28 \mathrm{mV}$. These data suggest that, in some motoneurons, vasopressin acted by increasing a nonselective cationic conductance, whereas in other motoneurons, it acted via a dual mechanism, i.e., by increasing a cationic conductance and by concomitantly decreasing a resting $\mathrm{K}^{+}$conductance.

\section{Effect of tachykinins on identified DM and DL pudendal motoneurons}

The effect of tachykinins was tested on a sample of seven DM pudendal motoneurons in the current-clamp mode. All of the motoneurons responded to tachykinins. Substance P $(0.1-1 \mu \mathrm{M})$ caused a depolarization in one motoneuron $(5 \mathrm{mV})$ and elicited action potential firing in four motoneurons (peak firing frequency, $9 \pm 1 \mathrm{~Hz}$; range, $5-10 \mathrm{~Hz}$ ) (Fig. 6A). In three motoneurons, recorded in the presence of TTX $(0.5 \mu \mathrm{M})$, the substance P-evoked depolarization was $11 \pm 1 \mathrm{mV}$ (range, 10-12 mV), indicating that this compound acted postsynaptically.

The pharmacological profile of the receptor mediating the effect of tachykinins in DM motoneurons was determined by

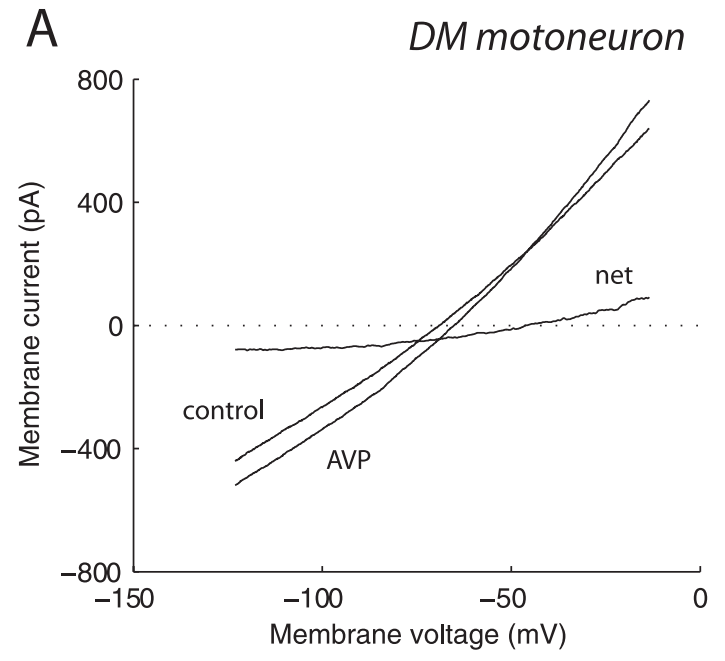

B

\section{DM motoneuron}

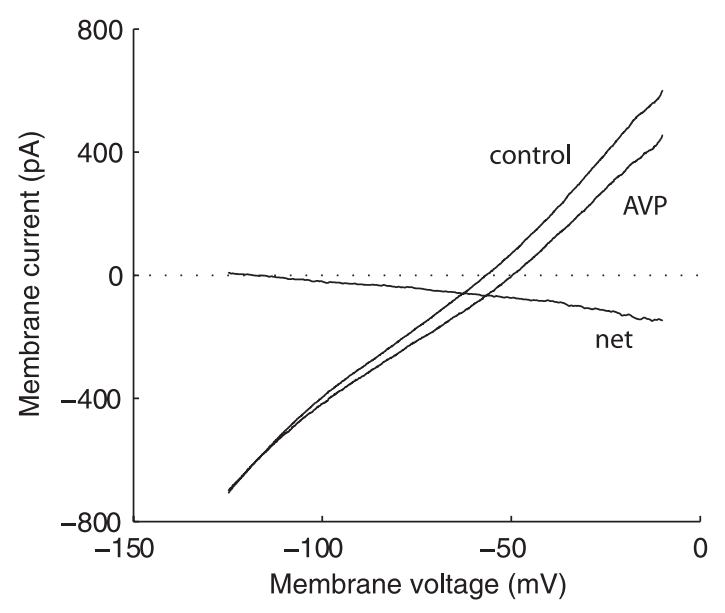

Figure 5. Current-voltage relationship of the vasopressin-activated current in identified DM pudendal motoneurons. $\boldsymbol{A}, \boldsymbol{B}$, Voltage-clamp commands were delivered as described in Results, in both the absence (control) and presence of $0.5 \mu \mathrm{m}$ vasopressin (AVP). The net vasopressin-evoked current was obtained by subtraction. The motoneurons were recorded using K-gluconate-containing patch pipettes. The perfusion solution was supplemented with 0.5 $\mu \mathrm{M}$ TTX. Note that, in the motoneuron in $A$, the vasopressin-evoked current reversed in polarity at approximately $-49 \mathrm{mV}$, whereas in the motoneuron in $\boldsymbol{B}$, it approached zero at approximately $-120 \mathrm{mV}$.

making use of selective agonists of tachykinin receptors. The selective NK1 receptor agonist sar ${ }^{9}$-SP $(0.1-0.2 \mu \mathrm{M})$ mimicked the effect of substance $\mathrm{P}(n=10)$. In four motoneurons, it induced a depolarization of $9 \pm 1 \mathrm{mV}$ (range, 7-10 mV), and, in two motoneurons, it elicited action potential firing (peak firing frequency, 7 and $11 \mathrm{~Hz}$ ) (Fig. $6 \mathrm{~B}$ ). In four motoneurons recorded in the presence of TTX $(0.5 \mu \mathrm{M})$, $\operatorname{sar}^{9}$-SP evoked a depolarization of $14 \pm 3 \mathrm{mV}$ (range, 5-19 mV) (Fig. 6C). The selective NK2 agonist $\beta$-ala-NKA $(0.5-1 \mu \mathrm{M} ; n=3)$ and the selective NK3 receptor agonist senktide $(0.1-0.2 \mu \mathrm{M} ; n=5)$ were without direct effect (Fig. 6A,B).

In the DL nucleus, substance $\mathrm{P}$ or sar $^{9}$-SP excited all 10 tested motoneurons. Substance P $(0.2-0.5 \mu \mathrm{M})$ caused a depolarization in two motoneurons ( $10 \mathrm{mV}$ in both cases) and induced action potential firing in three motoneurons (peak firing frequency, 1, 3, 


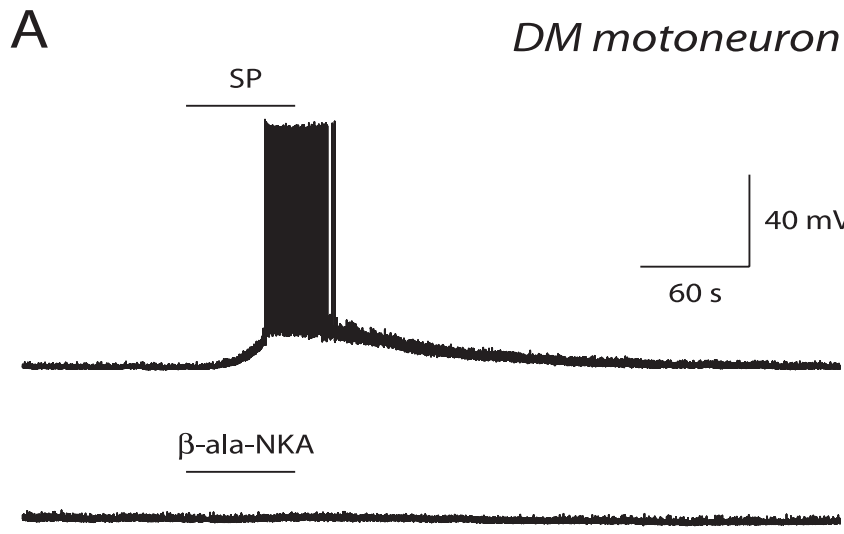

B

DM motoneuron

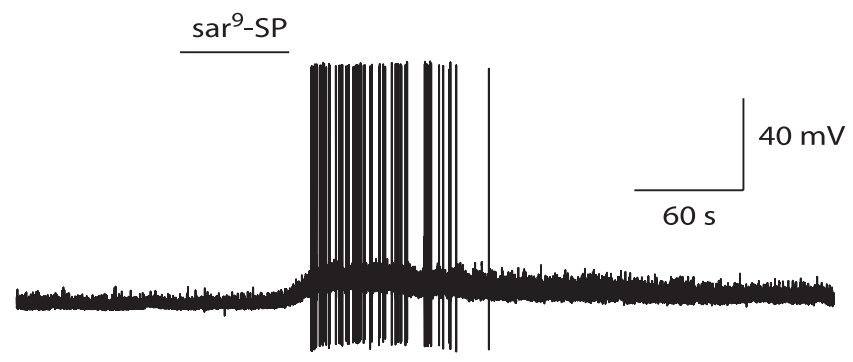

senktide

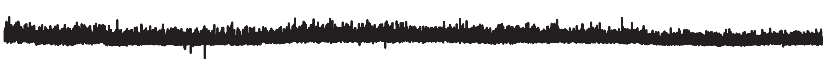

C

DM motoneuron

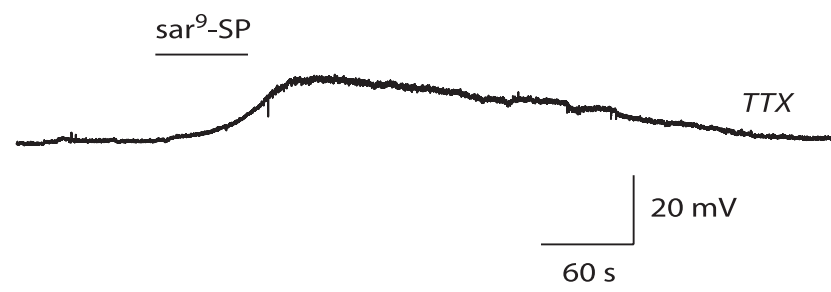

Figure 6. Effect of tachykinin receptor agonists on identified DM pudendal motoneurons. $A$, Current-clamp records obtained in the presence of $1 \mu \mathrm{m}$ substance $P$ (SP; top trace) and in the presence of $1 \mu \mathrm{m} \beta$-ala-NKA (bottom trace). $\boldsymbol{B}$, Current-clamp records obtained in a second motoneuron, in the presence of $0.1 \mu \mathrm{m} \mathrm{sar}{ }^{9}$-SP (top trace), and in the presence of $0.1 \mu \mathrm{m}$ senktide (bottom trace). $C$, Current-clamp recording obtained in a third motoneuron in the presence of $0.2 \mu \mathrm{m} \mathrm{sar}{ }^{9}$-SP. The perfusion solution was supplemented with $0.5 \mu \mathrm{m}$ TTX. Note that the effect of substance $\mathrm{P}$ was mimicked by $\operatorname{sar}^{9}$-SP, a selective NK1 receptor agonist, whereas $\beta$-ala-NKA and senktide, selective agonists of NK2 and NK3 receptors, respectively, were without effect. Note also that the effect of the NK1 receptor agonist persisted in the presence of TTX, i.e., in conditions of synaptic uncoupling.

and $4 \mathrm{~Hz})$. $\operatorname{sar}^{9}$-SP $(0.2-0.5 \mu \mathrm{M})$ elicited action potential firing (10 $\pm 2 \mathrm{~Hz}$; range, $3-16 \mathrm{~Hz} ; n=5$ ) (Fig. 7) or evoked, in the presence of TTX $(0.25 \mu \mathrm{M})$, a depolarization of $17 \pm 2 \mathrm{mV}$ (range, $10-20 \mathrm{mV} ; n=5$ ) (Fig. 7). $\beta$-ala-NKA (0.5 $\mu \mathrm{M} ; n=8$ )

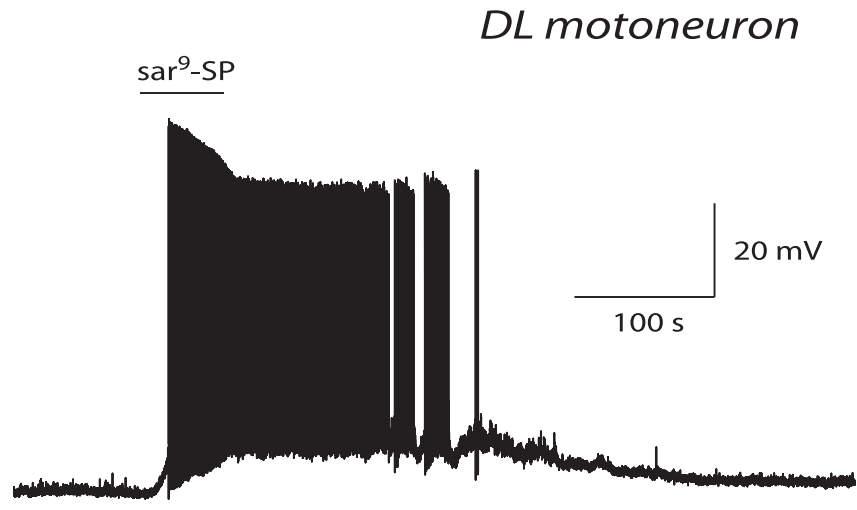

$\beta$-ala-NKA

senktide

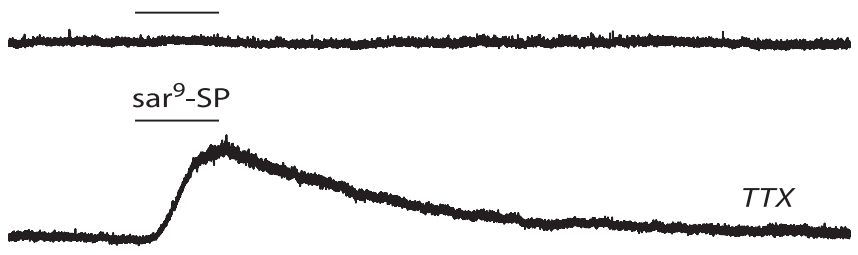

Figure 7. Effect of tachykinin receptor agonists on an identified DL pudendal motoneuron. Current-clamp records obtained in the presence of $0.5 \mu \mathrm{m} \mathrm{sar}{ }^{9}$-SP (top trace), $0.5 \mu \mathrm{m} \beta$-alaNKA (second trace), $0.5 \mu$ m senktide (third trace), and sar ${ }^{9}$-SP again, but now with $0.25 \mu$ M TTX added to the perfusion solution (bottom trace). Note that only sar ${ }^{9}$-SP, an NK1 receptor agonist, was effective in exciting the motoneuron and that its effect persisted in the presence of TTX.

and senktide ( $0.5 \mu \mathrm{M} ; n=7)$ were without direct effect (Fig. 7$)$. In some pudendal motoneurons (located in either the DM or DL nucleus), senktide caused an increase in membrane noise. This effect was indirect, because it was never observed in the presence of TTX.

Together, our data indicate that pudendal motoneurons, located in either the DM or the DL nucleus, were directly excited by tachykinins acting on NK1 receptors.

\section{Effect of tachykinins on identified nonpudendal motoneurons}

Recordings were performed in motoneurons innervating the hindleg, i.e., in six RDL motoneurons and in 15 lumbar motoneurons located rostrally to pudendal motoneurons. The data obtained in these two sets of motoneurons were similar and were pooled. They had a cell input resistance of $42 \pm 15 \mathrm{M} \Omega$ (range, 9-226 M $\Omega ; n=15)$. Substance $\mathrm{P}(0.1-0.5 \mu \mathrm{M})$ caused a depolarization in four motoneurons $(11 \pm 2 \mathrm{mV}$; range, $6-16 \mathrm{mV})$ and elicited action potential firing in six motoneurons (peak firing frequency, $10 \pm 2 \mathrm{~Hz}$; range, $3-15 \mathrm{~Hz}$ ). The selective NK1 receptor agonist $\operatorname{sar}^{9}-\mathrm{SP}(0.1-0.5 \mu \mathrm{M})$ mimicked the effect of substance P. In three motoneurons, it induced a depolarization of $16 \pm 6 \mathrm{mV}$ (range, 10-25 mV), and, in 10 motoneurons, it elicited action potential firing with a peak frequency of $19 \pm 2 \mathrm{~Hz}$ (range, 6-21 Hz) (Fig. 8A,B). In five additional motoneurons, recorded in the presence of TTX $(0.25 \mu \mathrm{M})$, sar $^{9}$-SP evoked a depolarization of $14 \pm 3 \mathrm{mV}$ (range, $6-20 \mathrm{mV}$ ) (Fig. $8 \mathrm{~B}$ ). The selective NK2 receptor agonist $\beta$-ala-NKA $(0.2-0.5 \mu \mathrm{M} ; n=10)$ and the selective NK3 receptor agonist senktide $(0.2-0.5 \mu \mathrm{M} ; n=$ 

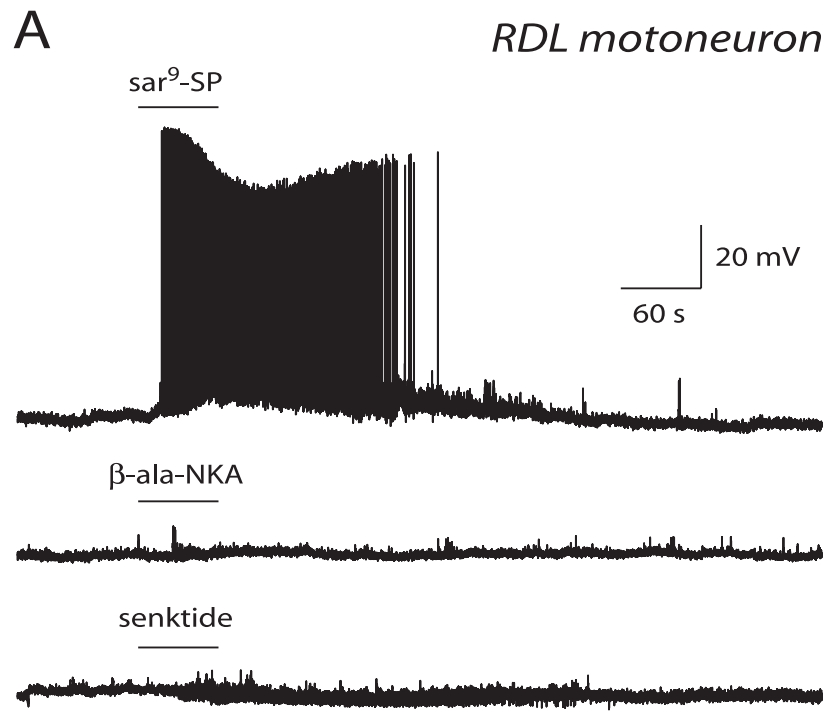

sar $^{9}-\mathrm{SP}$

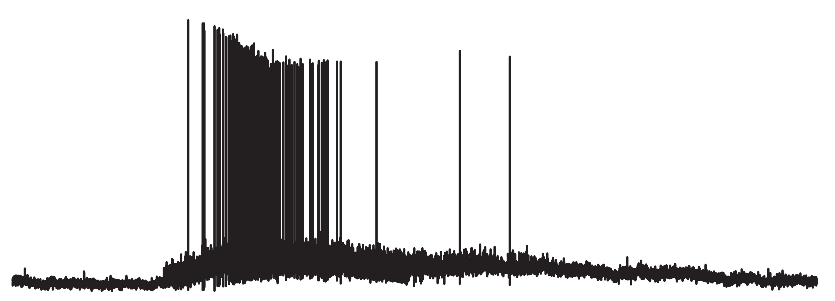

B

Lumbar motoneuron

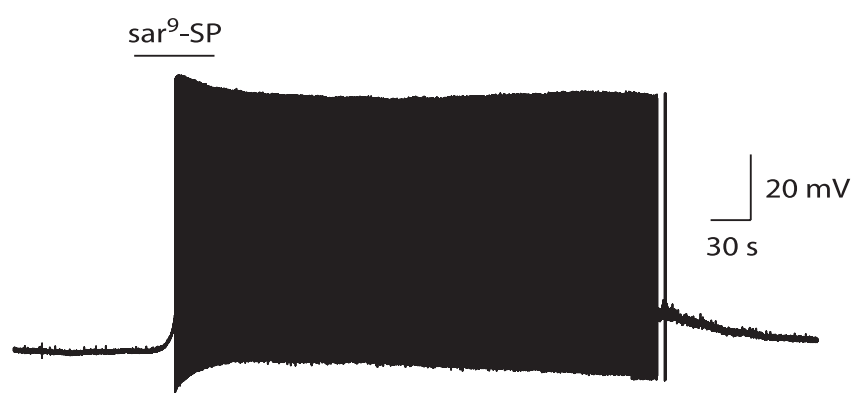

sar $^{9}-\mathrm{SP}$

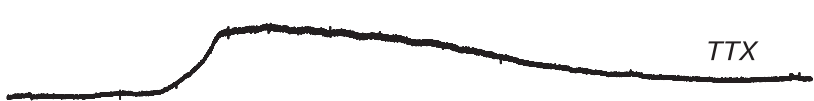

Figure 8. Effect of tachykinin receptor agonists on identified RDL and lumbar motoneurons. A, Current-clamp records obtained in an RDL motoneuron in the presence of $0.5 \mu \mathrm{m} \mathrm{sar}{ }^{9}$-SP (top trace), $0.5 \mu \mathrm{m} \beta$-ala-NKA (second trace), $0.5 \mu \mathrm{m}$ senktide (third trace), and sar ${ }^{9}$-SP again (bottom trace). $\boldsymbol{B}$, Current-clamp records obtained in a lumbar motoneuron in the presence of $0.5 \mu \mathrm{m} \mathrm{sar}{ }^{9}$-SP in control conditions (top trace) and after adjunction of $0.25 \mu \mathrm{m}$ TTX to the perfusion solution (bottom trace). Note that sar ${ }^{9}$-SP, an NK1 receptor agonist, caused excitation of the motoneuron, whereas $\beta$-ala-NKA and senktide, NK2 and NK3 receptor agonists, respectively, did not. Note also that the effect of the NK1 receptor agonist persisted in the presence of TTX and that senktide caused a slight increase in membrane noise.

10) were without direct effect (Fig. $8 A$ ). In some motoneurons, the NK3 receptor agonist senktide caused an increase in membrane noise (Fig. $8 \mathrm{~A}$, third trace). This effect was indirect, because it was never observed in the presence of TTX.
In conclusion, nonpudendal motoneurons located in either the RDL nucleus or lumbar motor nuclei are directly excited by tachykinins acting on NK1 receptors.

\section{Discussion}

Pharmacology of vasopressin and tachykinin effects on pudendal motoneurons

The present data show that spinal motoneurons located in the DM and DL nuclei can be powerfully excited by vasopressin and tachykinins. Despite their anatomical segregation and functional specialization, DM and DL pudendal motoneurons appear to possess a similar sensitivity to these compounds.

The action of vasopressin was attributable to activation of V1a but not V1b, V2, or oxytocin receptors. Our electrophysiological data are in good agreement with autoradiographic data showing the presence, in pudendal nuclei of male rats, of high-affinity vasopressin binding sites of the V1a type (Tribollet et al., 1997; Liu et al., 2003). The fact that vasopressin exerts a direct excitatory action on pudendal motoneurons indicates that the binding sites detected by autoradiography are at least in part localized on pudendal motoneurons and represent functional receptors.

We could not evidence any direct effect of TGOT, a selective oxytocin receptor agonist, on pudendal motoneurons. However, in some of them, TGOT caused an increase in membrane noise, probably attributable to enhanced synaptic input. A synaptically mediated inhibitory effect of vasopressin or oxytocin in lumbar motoneurons and in hypoglossal motoneurons has been characterized previously (Palouzier-Paulignan et al., 1994; Liu et al., 2003; Reymond-Marron et al., 2005).

The excitatory action of tachykinins on pudendal motoneurons was mediated exclusively by NK1 receptors. Although the pharmacological profile of substance $\mathrm{P}$ binding sites present in rat pudendal nuclei has not been characterized (Charlton and Helke, 1985), several morphological studies indicate that spinal nonpudendal as well as brainstem motoneurons express predominantly NK1, rather than NK2 or NK3, receptors (for review, see Rekling et al., 2000). However, the expression of tachykinin receptors in motoneurons varies during development. Thus, up to $10 \mathrm{~d}$ of age, a majority of tachykinin binding sites present in the ventral horn of the lumbar spinal cord are of the NK3 type (Beresford et al., 1992). The apparent discrepancy between these morphological data and our electrophysiological findings could be explained by postulating that NK3 receptors are absent from or weakly expressed in motoneurons but may be present on premotor cells. Accordingly, we found that, in some motoneurons, an NK3-selective agonist could elicit an increase in membrane noise. This effect was indirect, because it was undetectable in the presence of TTX and was probably attributable to an agonistinduced increase in synaptic activity.

\section{Comparison with nonpudendal motoneurons}

Recently, we characterized the action of vasopressin on lumbar motoneurons, which innervate the hindleg and are located at spinal segments rostral to those containing pudendal motoneurons (Liu et al., 2003). We found that, in young rats, vasopressin directly excited lumbar motoneurons. This effect was mediated by V1a but not V1b or V2 receptors. Vasopressin also enhanced the GABAergic and glycinergic input to motoneurons by exciting inhibitory premotor neurons.

In the present study, we investigated the responsiveness to tachykinins of motoneurons innervating the hindleg and located in either the RDL nucleus or lumbar motor nuclei. These mo- 
toneurons were excited by either substance $\mathrm{P}$ or an NK1 receptor agonist. This effect was postsynaptic, because it persisted in the presence of TTX, i.e., in conditions of synaptic uncoupling. In contrast, NK2 and NK3 receptor agonists were ineffective in eliciting any direct response. It has been reported by others that tachykinins can induce depolarization or generate an inward current in nonpudendal spinal motoneurons or in brainstem motoneurons (Konishi and Otsuka, 1974; Otsuka and Yanagisawa, 1980; Fisher and Nistri, 1993; Fisher et al., 1994; Ptak et al., 2000; Yasuda et al., 2001).

Together, our data indicate that pudendal motoneurons and motoneurons innervating the hindleg share a common sensitivity to vasopressin and tachykinins. Our study was performed in developing motoneurons, at a stage at which pudendal motoneurons do not yet express androgen receptors (Jordan et al., 1997). Are pudendal motoneurons from adults also responsive to vasopressin and tachykinins? In adult male rats, pudendal motor nuclei contain vasopressin and tachykinin binding sites (Charlton and Helke, 1985; Tribollet et al., 1997), a fact that contrasts with what is found in other spinal motor nuclei and brainstem motor nuclei, in which these binding sites are detectable in neonate but not in adults (Quirion and Dam, 1986; Tribollet et al., 1991, 1994). This suggests that pudendal motoneurons of adults can be excited by vasopressin and tachykinins. A direct demonstration would require recording from adult motoneurons. Unfortunately, this is a very difficult task. For reasons that are not yet clear, adult mammalian motoneurons survive poorly in vitro. Despite various attempts to overcome this difficulty, such as dissection in $\mathrm{Na}^{+}$-free medium (Aghajanian and Rasmussen, 1989), coculture with muscle cells (Gueritaud and Seyfritz, 1992), or adjunction of neurotrophic factors to culture media (Hanson et al., 1998), no efficient technology allowing the systematic survival of adult motoneurons in vitro is presently available.

\section{Mechanism of action of vasopressin}

$I-V$ relationships suggest that, in some pudendal motoneurons, vasopressin acted by enhancing a nonselective cationic conductance. In some other motoneurons, it probably exerted a dual effect: it enhanced a cationic conductance and, concomitantly, it suppressed a resting $\mathrm{K}^{+}$conductance. We could not find any evidence that vasopressin could act solely by suppressing a $\mathrm{K}^{+}$ conductance. Indeed, (1) the vasopressin response persisted in motoneurons loaded with $\mathrm{Cs}$, a nonspecific blocker of $\mathrm{K}^{+}$channels; (2) in motoneurons in which the peptide-induced current was a linear function of membrane potential, zero current level was attained at potentials much more negative than the $\mathrm{K}^{+}$equilibrium potential, $E_{\mathrm{K}}$, which, in our conditions, was $-85 \mathrm{mV}$.

A mechanism involving both a cationic conductance and $\mathrm{K}^{+}$ conductance has been proposed for the excitatory action of vasopressin in spinal lateral horn neurons and lumbar motoneurons of neonate rats (Kolaj and Renaud, 1998; Oz et al., 2001). In facial and hypoglossal motoneurons of young rats, vasopressin was found to exert its excitatory action mainly, if not exclusively, by increasing a persistent, voltage-dependent cationic conductance (Raggenbass et al., 1991; Alberi et al., 1993; Palouzier-Paulignan et al., 1994).

In the present study, we did not address the membrane mechanism by which tachykinins excited pudendal motoneurons. Previous studies suggest that blockade of a $\mathrm{K}^{+}$conductance may be involved. In neonatal lumbar motoneurons, the substance $\mathrm{P}$-evoked depolarization was attributable to the suppression of a $\mathrm{Ba}^{+}$-sensitive $\mathrm{K}^{+}$conductance (Fisher and Nistri, 1993). In phrenic motoneurons and in hypoglossal motoneurons, NK1 receptor activation induced membrane depolarization, or evoked an inward current, by inhibiting a resting $\mathrm{K}^{+}$current (Ptak et al., 2000; Yasuda et al., 2001). In hypoglossal motoneurons, this excitatory effect was at least in part mediated by the two-pore domain $\mathrm{K}^{+}$channel TASK-1 (TWIK-related acid-sensitive $\mathrm{K}^{+}$ channels) (Talley et al., 2000). Additional studies are needed to determine whether similar tachykinin-induced changes in membrane permeability take place in pudendal motoneurons.

\section{Possible origin of peptidergic innervation of pudendal motoneurons}

Electrolytic lesion studies and retrograde tracing studies indicate that, in the rat and the cat, specific projections to pudendal motor nuclei originate from various brain areas, including the paraventricular hypothalamic nucleus (Holstege and Tan, 1987; Wagner and Clemens, 1991; Monaghan et al., 1993). At least part of the spinal projection arising from the paraventricular nucleus is vasopressinergic (Wagner and Clemens, 1993; Hallbeck and Blomqvist, 1999), suggesting that vasopressin-containing axons originating from the hypothalamus contact pudendal motoneurons. In the cat, pudendal motoneurons are also contacted by substance P-containing axons (Tashiro et al., 1989a). The majority of them are of intraspinal origin and originate probably from neurons located around the central canal, at the level of Onuf's nucleus (Tashiro et al., 1989b). Thus, pudendal motoneurons appear to be the target of a dual peptidergic control. One is of central origin and is mediated by vasopressin, and one is of local origin and is mediated by tachykinins.

\section{Functional considerations}

In contrast to spinal motoneurons innervating the trunk and limb muscles and to brainstem motoneurons, virtually nothing is known about the pharmacological properties of pudendal motoneurons, and the present study is to our knowledge the first to address this issue. Our data indicate that vasopressin and tachykinins can regulate the activity of pudendal motoneurons. By modifying the intrinsic bioelectrical properties of motoneurons, vasopressin and tachykinins can modulate their input-output relationship (Hultborn and Kiehn, 1992; Pierson et al., 2001) and act as regulators of muscular force. These compounds can thus influence eliminative functions of the bladder and intestine as well as sexual function by facilitating the activity of striated perineal muscles. In humans, lesion of structures controlling the activity of pudendal motoneurons can have devastating consequences. Knowing how neurotransmitters/neuromodulators influence pudendal motoneuron activity may be relevant in view of shaping strategies for the pharmacological control of alterations of eliminative and sexual functions observed in case of spinal cord injury or neurological diseases.

\section{References}

Aghajanian GK, Rasmussen K (1989) Intracellular studies in the facial nucleus illustrating a simple new method for obtaining viable motoneurons in adult rat brain slices. Synapse 3:331-338.

Alberi S, Dubois-Dauphin M, Dreifuss JJ, Raggenbass M (1993) Modulation by divalent cations of the current generated by vasopressin in facial motoneurons. Brain Res 624:326-330.

Beresford IJ, Ireland SJ, Stables J, Hagan RM (1992) Ontogeny and characterization of $\left[{ }^{125} \mathrm{I}\right]$ Bolton Hunter-eledoisin binding sites in rat spinal cord by quantitative autoradiography. Neuroscience 46:225-232.

Breedlove SM, Arnold AP (1980) Hormone accumulation in a sexually dimorphic motor nucleus of the rat spinal cord. Science 210:564-566. 
Breedlove SM, Arnold AP (1983) Hormonal control of a developing neuromuscular system. I. Complete demasculinization of the male rat spinal nucleus of the bulbocavernosus using the anti-androgen flutamide. J Neurosci 3:417-423.

Charlton CG, Helke CJ (1985) Autoradiographic localization and characterization of spinal cord substance P binding sites: high densities in sensory, autonomic, phrenic, and Onuf's motor nuclei. J Neurosci 5:1653-1661.

Derick S, Cheng LL, Voirol MJ, Stoev S, Giacomini M, Wo NC, Szeto HH, Ben Mimoun M, Andres M, Gaillard RC, Guillon G, Manning M (2002) [1-deamino-4-cyclohexylalanine] arginine vasopressin: a potent and specific agonist for vasopressin V1b receptors. Endocrinology 143:4655-4664.

Fedirchuk B, Shefchyk SJ (1993) Membrane potential changes in sphincter motoneurons during micturition in the decerebrate cat. J Neurosci 13:3090-3094.

Fedirchuk B, Downie JW, Shefchyk SJ (1994) Reduction of perineal evoked excitatory postsynaptic potentials in cat lumbar and sacral motoneurons during micturition. J Neurosci 14:6153-6159.

Fisher ND, Nistri A (1993) Substance P and TRH share a common effector pathway in rat spinal motoneurones: an in vitro electrophysiological investigation. Neurosci Lett 153:115-119.

Fisher ND, Baranauskas G, Nistri A (1994) Multiple types of tachykinin receptor mediate a slow excitation of rat spinal motoneurones in vitro. Neurosci Lett 165:84-88.

Grzonka Z, Lammek B, Kasprzykowski F, Gazis D, Schwartz IL (1983) Synthesis and some pharmacological properties of oxytocin and vasopressin analogues with sarcosine or $\mathrm{N}$-methyl-L-alanine in position 7. J Med Chem 26:555-559.

Gueritaud JP, Seyfritz N (1992) An organotypic co-culture of embryonic rat brainstem and tongue or skeletal muscle. Eur J Neurosci 4:616-627.

Hallbeck M, Blomqvist A (1999) Spinal cord-projecting vasopressinergic neurons in the rat paraventricular hypothalamus. J Comp Neurol 411:201-211.

Hanson Jr MG, Shen S, Wiemelt AP, McMorris FA, Barres BA (1998) Cyclic AMP elevation is sufficient to promote the survival of spinal motor neurons in vitro. J Neurosci 18:7361-7371.

Holstege G, Tan J (1987) Supraspinal control of motoneurons innervating the striated muscles of the pelvic floor including urethral and anal sphincters in the cat. Brain 110:1323-1344.

Hultborn H, Kiehn O (1992) Neuromodulation of vertebrate motor neuron membrane properties. Curr Opin Neurobiol 2:770-775.

Jordan CL, Breedlove SM, Arnold AP (1982) Sexual dimorphism and the influence of neonatal androgen in the dorsolateral motor nucleus of the rat lumbar spinal cord. Brain Res 249:309-314.

Jordan CL, Letinsky MS, Arnold AP (1989) The role of gonadal hormones in neuromuscular synapse elimination in rats. II. Multiple innervation persists in the adult levator ani muscle after juvenile androgen treatment. J Neurosci 9:239-247.

Jordan CL, Padgett B, Hershey J, Prins G, Arnold A (1997) Ontogeny of androgen receptor immunoreactivity in lumbar motoneurons and in the sexually dimorphic levator ani muscle of male rats. J Comp Neurol 379:88-98.

Kihira T, Yoshida S, Yoshimasu F, Wakayama I, Yase Y (1997) Involvement of Onuf's nucleus in amyotrophic lateral sclerosis. J Neurol Sci 147:81-88.

Kolaj M, Renaud LP (1998) Vasopressin-induced currents in rat neonatal spinal lateral horn neurons are G-protein mediated and involve two conductances. J Neurophysiol 80:1900-1910.

Koliatsos VE, Price DL, Clatterbuck RE (1994) Motor neurons in Onuf's nucleus and its rat homologues express the $\mathrm{p} 75$ nerve growth factor receptor: sexual dimorphism and regulation by axotomy. J Comp Neurol 345:510-527.

Konishi S, Otsuka M (1974) Excitatory action of hypothalamic substance P on spinal motoneurones of newborn rats. Nature 252:734-735.

Leong SK, Ling EA (1990) Labelling neurons with fluorescent dyes administered via intravenous, subcutaneous or intraperitoneal route. J Neurosci Methods 32:15-23.

Liu X, Tribollet E, Ogier R, Barberis C, Raggenbass M (2003) Presence of functional vasopressin receptors in spinal ventral horn neurons of young rats: a morphological and electrophysiological study. Eur J Neurosci 17:1833-1846.
Lowbridge J, Manning M, Haldar J, Sawyer WH (1977) Synthesis and some pharmacological properties of [4-threonine, 7- glycine] oxytocin, [1-(L-2hydroxy-3-mercaptopropanoic acid), 4- threonine, 7-glycine] oxytocin (hydroxy[Thr4, Gly7]oxytocin), and [7-glycine] oxytocin, peptides with high oxytocic-antidiuretic selectivity. J Med Chem 20:120-123.

Manabe T, Araki I, Takahashi T, Kuno M (1991) Membrane currents recorded from sexually dimorphic motoneurones of the bulbocavernosus muscle in neonatal rats. J Physiol (Lond) 440:419-435.

Mannen T (2000) Neuropathological findings of Onuf's nucleus and its significance. Neuropathology [Suppl] 20:S30-S33.

Manning M, Bankowski K, Barberis C, Jard S, Elands J, Chan WY (1992) Novel approach to the design of synthetic radioiodinated linear V1A receptor antagonists of vasopressin. Int J Pept Protein Res 40:261-267.

McKenna KE, Nadelhaft I (1986) The organization of the pudendal nerve in the male and female rat. J Comp Neurol 248:532-549.

Monaghan EP, Arjomand J, Breedlove SM (1993) Brain lesions affect penile reflexes. Horm Behav 27:122-131.

Nacimiento W, Topper R, Fischer A, Mobius E, Oestreicher AB, Gispen WH, Nacimiento AC, Noth J, Kreutzberg GW (1993) B-50 (GAP-43) in Onuf's nucleus of the adult cat. Brain Res 613:80-87.

Nordeen EJ, Nordeen KW, Sengelaub DR, Arnold AP (1985) Androgens prevent normally occurring cell death in a sexually dimorphic spinal nucleus. Science 229:671-673.

Otsuka M, Yanagisawa M (1980) The effects of substance P and baclofen on motoneurones of isolated spinal cord of the newborn rat. J Exp Biol 89:201-214.

Oz M, Kolaj M, Renaud LP (2001) Electrophysiological evidence for vasopressin $\mathrm{V}(1)$ receptors on neonatal motoneurons, premotor and other ventral horn neurons. J Neurophysiol 86:1202-1210.

Palouzier-Paulignan B, Dubois-Dauphin M, Tribollet E, Dreifuss JJ, Raggenbass M (1994) Action of vasopressin on hypoglossal motoneurones of the rat: presynaptic and postsynaptic effects. Brain Res 650:117-126.

Peshori KR, Erichsen JT, Collins III WF (1995) Differences in the connectivity of rat pudendal motor nuclei as revealed by retrograde transneuronal transport of wheat germ agglutinin. J Comp Neurol 353:119-128.

Pierson P, Tribollet E, Raggenbass M (2001) Effect of vasopressin on the input-output properties of rat facial motoneurons. Eur J Neurosci 14:957-967.

Ptak K, Konrad M, Di Pasquale E, Tell F, Hilaire G, Monteau R (2000) Cellular and synaptic effect of substance $P$ on neonatal phrenic motoneurons. Eur J Neurosci 12:126-138.

Pullen AH, Tucker D, Martin JE (1997) Morphological and morphometric characterisation of Onuf's nucleus in the spinal cord in man. J Anat 191:201-213.

Quirion R, Dam TV (1986) Ontogeny of substance P receptor binding sites in rat brain. J Neurosci 6:2187-2199.

Raggenbass M, Goumaz M, Sermasi E, Tribollet E, Dreifuss JJ (1991) Vasopressin generates a persistent voltage-dependent sodium current in a mammalian motoneuron. J Neurosci 11:1609-1616.

Regoli D, Drapeau G, Dion S, Couture R (1988) New selective agonists for neurokinin receptors: pharmacological tools for receptor characterization. Trends Pharmacol Sci 9:290-295.

Regoli D, Boudon A, Fauchere JL (1994) Receptors and antagonists for substance $P$ and related peptides. Pharmacol Rev 46:551-599.

Rekling JC, Funk GD, Bayliss DA, Dong XW, Feldman JL (2000) Synaptic control of motoneuronal excitability. Physiol Rev 80:767-852.

Reymond-Marron I, Raggenbass M, Zaninetti M (2005) Vasopressin facilitates glycinergic and GABAergic synaptic transmission in developing hypoglossal motoneurons. Eur J Neurosci 21:1601-1609.

Roppolo JR, Nadelhaft I, de Groat WC (1985) The organization of pudendal motoneurons and primary afferent projections in the spinal cord of the rhesus monkey revealed by horseradish peroxidase. J Comp Neurol 234:475-488.

Sachs BD (1982) Role of striated penile muscles in penile reflexes, copulation, and induction of pregnancy in the rat. J Reprod Fertil 66:433-443.

Sasaki M (1991) Membrane properties of external urethral and external anal sphincter motoneurones in the cat. J Physiol (Lond) 440:345-366.

Sawyer WH, Grzonka Z, Manning M (1981) Neurohypophysial peptides. Design of tissue-specific agonists and antagonists. Mol Cell Endocrinol 22:117-134. 
Schroder HD (1980) Organization of the motoneurons innervating the pelvic muscles of the male rat. J Comp Neurol 192:567-587.

Talley EM, Lei Q, Sirois JE, Bayliss DA (2000) TASK-1, a two-pore domain $\mathrm{K}^{+}$channel, is modulated by multiple neurotransmitters in motoneurons. Neuron 25:399-410.

Tashiro T, Satoda T, Matsushima R, Mizuno N (1989a) Convergence of serotonin-, enkephalin- and substance P-like immunoreactive afferent fibers on single pudendal motoneurons in Onuf s nucleus of the cat: a light microscope study combining the triple immunocytochemical staining technique with the retrograde HRP-tracing method. Brain Res 481:392-398.

Tashiro T, Satoda T, Matsushima R, Mizuno N (1989b) Possible origins of substance P-like immunoreactive axons within Onuf's nucleus of the cat. Brain Res 497:177-182.

Tribollet E, Goumaz M, Raggenbass M, Dubois-Dauphin M, Dreifuss JJ (1991) Early appearance and transient expression of vasopressin receptors in the brain of rat fetus and infant. An autoradiographical and electrophysiological study. Brain Res Dev Brain Res 58:13-24.

Tribollet E, Arsenijevic Y, Marguerat A, Barberis C, Dreifuss JJ (1994) Axo- tomy induces the expression of vasopressin receptors in cranial and spinal motor nuclei in the adult rat. Proc Natl Acad Sci USA 91:9636-9640.

Tribollet E, Barberis C, Arsenijevic Y (1997) Distribution of vasopressin and oxytocin receptors in the rat spinal cord: sex-related differences and effect of castration in pudendal motor nuclei. Neuroscience 78:499-509.

Ueyama T, Mizuno N, Nomura S, Konishi A, Itoh K, Arakawa H (1984) Central distribution of afferent and efferent components of the pudendal nerve in cat. J Comp Neurol 222:38-46.

Wagner CK, Clemens LG (1991) Projections of the paraventricular nucleus of the hypothalamus to the sexually dimorphic lumbosacral region of the spinal cord. Brain Res 539:254-262.

Wagner CK, Clemens LG (1993) Neurophysin-containing pathway from the paraventricular nucleus of the hypothalamus to a sexually dimorphic motor nucleus in lumbar spinal cord. J Comp Neurol 336:106-116.

Yasuda K, Robinson DM, Selvaratnam SR, Walsh CW, McMorland AJ, Funk GD (2001) Modulation of hypoglossal motoneuron excitability by NK1 receptor activation in neonatal mice in vitro. J Physiol (Lond) 534:447-464. 